\title{
Determination of Optimum Environmental Conservation: Using Multi-Criteria Decision-Making Techniques
}

\author{
H. MURAT ÇELIK* \& ERSIN TÜRK** \\ *Department of City and Regional Planning, Izmir Institute of Technology, Urla Izmir, Turkiye, \\ ** Department of City and Regional Planning, Technical University of Karadeniz, Trabzon, Turkiye
}

(Received November 2009; accepted March 2010)

\begin{abstract}
The type and degree of conservation areas in Turkey legally dictate the kind of land uses that can and cannot take place in a conservation area. Thus, the conservation scheme is one of the most important criteria in designing an urban land-use plan. The aim of this study is to analyse the effects of various conservation decisions on land-use allocation holding everything else constant. This study uses a land-allocation mathematical programme formulated by Hanink and Cromley [(1998) Land-use allocation in the absence of complete market values, Journal of Regional Science, 38, pp. 465-480] that integrates the geographical information systems with a generalized assignment problem to determine an optimum level of conservation scheme in Cesme/Izmir, a coastal resort in Turkey. The findings state that the proposed technique is indeed very useful and promising to answer diversified practical issues on a more rational basis.
\end{abstract}

\section{Introduction}

The advances in computers and information technology have been making many analytical tools more and more available for daily usage by academicians, professionals and decision-makers. The framework proposed by Hanink and Cromley (1998) is indeed a very promising one among these tools for land-use planners and decision-makers. In their study, Hanink and Cromley developed a technique to achieve an optimum allocation of competing land uses in the absence of complete market values by integrating the multicriteria decision-making (MCDM) tools and a binary integer programming. In their study, the application of the technique was presented with a pure numerical example including

Correspondence Address: Ersin Türk, Department of City and Regional Planning, Technical University of Karadeniz, Trabzon, Turkiye. Email: ersinturk@ktu.edu.tr 
three competing generic land uses on a hypothetical piece of land. Thus, the real-life applications and the practicality of the technique stand as a further research subject.

Beyond the stated intention and implication, the technique seems very convenient for answering the diversified policy questions in urban areas. These questions may include determining the optimum-level urban amenities in contrast to their desired or imposed levels via their estimated shadow prices; evaluating the proposed or competing land-use plan alternatives in comparison to optimum land-use allocation (via objective function value of optimum allocation and the parcels' shadow prices inherent to the technique); establishing physical boundaries of environmentally, naturally or archaeologically sensitive areas and determining residential or commercial densities under a city-wide agreed valuation scheme. The analytical tools required to quantify the above-stated issues are very limited, and these issues have always been very argumentative in the urban landuse planning profession. The intention of this paper is to show empirical performance and usage of the Hanink and Cromley (1998) formulation on certain planning issues with a case study adding practical dimension to a hypothetical study. In this way, we expect that we could provide a deeper understanding for analysing certain intangibilities in urban land-use planning.

The Von Thünen model (Hall, 1966) provides basic rent determination and land-use allocation in urban areas. According to the model, competing land uses bid for land in urban areas to be closer to the centre where the market takes place and the rent is the highest. Thus, the rent appears as a transport cost differential that is capitalized into the land value. Naturally, locational sequence away from the centre occurs with respect to economic profitability/productivity of the land uses. Under this configuration, it is not possible to say that a market-driven spatial configuration is socially optimum in case there had to be environmentally or socially desirable land uses with no explicit profit measures. Land-use allocation that takes positive externalities of socially desirable uses into consideration is called as the second best allocation (see Hanink \& Cromley, 1998, for details).

A broad family of the techniques used to determine the second best allocation is "MCDM". MCDM techniques in connection with geographical information systems (GIS) have been extensively used in resource-allocation problems of environment/ ecology, transportation, urban/regional planning, waste management, hydrology, agriculture and forestry since the 1990s (Malczewski, 2006a). One subsection of MCDM techniques is "multi-criteria analysis" (MCA), which may be used for the preparation of a land suitability evaluation map for a given land use(s) or facility (Pereira \& Duckstein, 1993; Malczewski, 1996, 2006b; Dai et al., 2001; Joerin et al., 2001; Banai, 2005; Natividade-Jesus et al., 2007) and for the evaluation of a predetermined and limited number of allocation alternatives with respect to each other (e.g. Carver, 1991; Bodini \& Giavelli, 1992; Zucca et al., 2007). MCA is a useful and simple evaluation and selection technique when the alternatives are available. However, in many cases, the set of allocation alternatives are not available, or difficult to define. In such cases, multi-objective decision analysis (MODA) is used as the second basic technique of MCDM that generally generates optimal allocation alternatives using optimization techniques. MCDM is widely used for optimum land-use allocation in land-use planning (Bammi \& Bammi, 1979; Gilbert et al., 1985; Chuvieco, 1993; Dokmeci et al., 1993; Grabaum \& Meyer, 1998; Gabriel et al., 2006; Ligmann-Zielinska et al., 2008), in the determination of facility locations (Malczewski, 1991; Minor \& Jacobs, 1994; Eastman et al., 1995; Maniezzo et al., 
1998; Cheng et al., 2003), in land-allocation problem with a shape constraint such as compactness (Aerts \& Heuvelink, 2002; Aerts et al., 2003), convexity and contiguity (Minor \& Jacob, 1994; Williams, 2003; Shirabe, 2005) and environmental conflict analysis (Malczewski et al., 1997). Besides, Malczewski and Ogryczak (1995, 1996) discussed multiple criteria location problem with MCDA methods. MODA is a design technique because it defines the best solution or alternative with mathematical optimization techniques, especially when competing land uses are present.

The model used in this empirical research is a MODA (single objective problem) technique formulating the land allocation as a binary linear programming (Hanink \& Cromley, 1998). Since explicit market prices are not directly observable for social utilities or environmental assets, suitability indexes are used as proxies for the market prices of such assets in the program. Estimation of the suitability indexes again uses other MCDM techniques, as it will be explained shortly. Cromley and Hanink (1999, 2003) employed this model in their two subsequent studies, but in settings that were completely different from those used in the present paper. One of them (Cromley \& Hanink, 1999) tested the algorithm of the model with IDRISI software estimation, while the other (Cromley \& Hanink, 2003) tested the allocative behaviour of the model using realworld data again to check the estimation algorithm. The present study, on the other hand, tested the model's applicability to a specific issue in the professional practice.

Our case study, Cesme, is a small town at the Aegean Cost of Turkiye (Figure 1). Like many other coastal towns at the West and South of Turkiye, Cesme is also the destination of national and international mass summer tourism since 1980s. The city has many natural, environmental and archaeological endangered assets due to such a high demand and mass consumption of tourism. Since 1990, rising awareness of the environment has brought the concept of "conservation and usage equilibrium" as a sustainable planning approach in these towns. Planners have always been supportive of full conservation, while the users and entrepreneurs of the city supported the maximum use of the resources. Within the last 20 years, four different conservation schemes were ruled and imposed in the city with different geographical coverage. However, rationality and reasoning of these schemes have never been resolved among different parties of interests, and the discussions about them still continue. In 2007, the Municipality of Cesme had initiated a new planning study, and the recent question: "which one of the conservation schemes should be taken as the basis for the new city plan?" was the focal point. This paper attempted to resolve this focal issue with the above-explained technique. Furthermore, using the inherent properties

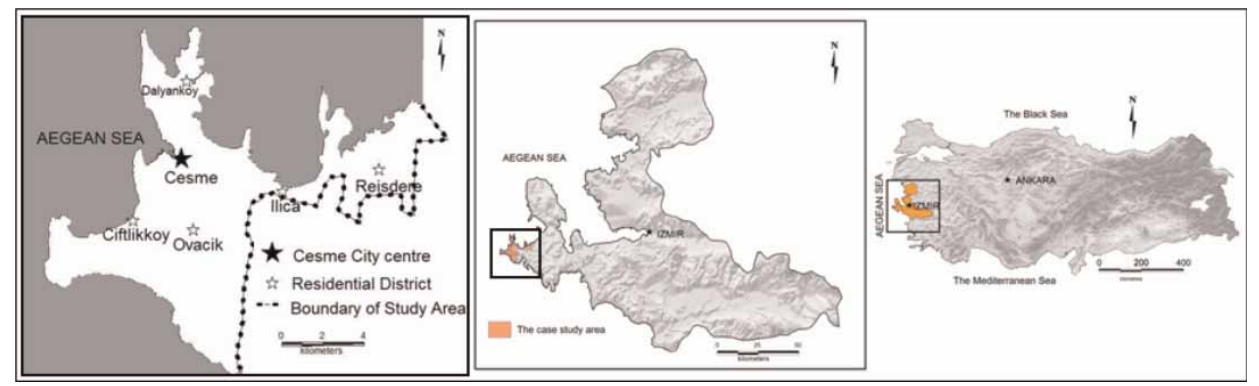

Figure 1. Location of Izmir and the study area 
of the technique, the optimum amount and densities of land uses and other possible usage of the model are also discussed in this study.

The next section explains the technique used in this study. Section 3 presents the description of the study area. Section 4 is devoted to the explanation about data preparation. Section 5 explains the results and the final section concludes the paper.

\section{Land Assignment Model}

The land assignment model used in this study was formulated as a binary integer programming model. In this formulation, urban area is assumed as a collection of discrete equal sized grids (i.e. each grid represents one distinct parcel), and each grid is assigned to a single land use with respect to some measurement of its value. Then, the objective is to maximize the total value of the urban area. It is mathematically stated as follows (Hanink \& Cromley, 1998):

$$
\begin{gathered}
\text { maximize }: \sum_{i=1}^{n} \sum_{j=1}^{m} S_{i j}^{\prime} X_{i j}, \\
\text { subjectto }: \sum_{j=1}^{m} X_{i j} \leq 1, \quad(2) \\
\sum_{i=1}^{n} X_{i j}=D_{j}, \quad(3) \\
X_{i j}=0 \text { or } 1 \quad \forall i, j,
\end{gathered}
$$

where $n$ is the number of land parcels, $m$ is the number of land uses, $X_{i j}$ is the decision variable assigning the $i$ th land parcel to the $j$ th land use, $S_{i j}$ ' is a suitability measurement of the parcel $i$ when it is assigned to the $j$ th land use and $D_{j}$ is the demand level for the $j$ th land use.

The first constraint by Equation (2) guarantees that each parcel is assigned to only one use among $m$ alternative land uses because only competing land uses were considered in this study. Equation (3) states that the total assignment of a given land use must be equal to a predetermined number of parcels (i.e. total demand). It should be noted that there may not be a constraint for every land use. If the total number of grids for a land use is not specified, then it will be determined internally. Furthermore, the constraint could also be specified as "greater/smaller or equal than" to a predetermined value. The dual formulation of this program is specified as

$$
\begin{aligned}
& \operatorname{minimize}: \sum_{j=1}^{m} D_{j} C_{j}+\sum_{i=1}^{n} R_{i}, \\
& \text { subjectto }: C_{j}+R_{i} \geq S_{i j}^{\prime}, \quad(6)
\end{aligned}
$$

where $C_{j}$ is the shadow price associated with the demand for each land use and $R_{i}$ is the shadow price associated with the demand for each parcel.

In terms of market prices, we could interpret $R_{i}$ as the ideal market price in a perfect equilibrium (Barr, 1973), while $C_{j}$ is the total urban utility of the respective land use 
that one additional unit increases the total urban benefit as much as $C_{j}$ as long as the total amount of $j$ th land use is defined as a constraint in the program. Even if we do not have explicit market prices, derived values of these shadow prices are very useful proxies, and give us immense opportunities to evaluate land-use policies in an urban area, as we will see shortly.

Specification of $S_{i j}^{\prime}$ establishes the most essential part of this model since it is a direct proxy for the real market prices as a suitability score. The elaboration on this would eventually produce consistent and reliable results. The suitability scores of every parcel for each land-use type are measured and standardized according to the parcel's site and situation characteristics. Site characteristics measure the quality, while situation characteristics measure the accessibility of the parcel. In this measurement, MCDM techniques and GIS were successfully integrated.

In the second step, a composite suitability index is estimated as the linearly weighted combination of the suitability scalars:

$$
S_{i j}=\sum_{k=1}^{P_{j}} w_{i j k} A_{i j k}^{\prime} \quad \forall i, j,
$$

where $S_{i j}$ is the composite suitability index, $P_{j}$ is the number of criteria for the $j$ th land use, $w_{i j k}$ is the weight of the $k$ th criterion with respect to the $j$ th potential land use for the $i$ th parcel and $A_{i j k}^{\prime}$ is the suitability scalar of the $i$ th parcel for the $j$ th land use with respect to the $k$ th criterion.

The suggested methodology for estimating the criterion combinatorial weights is the pair-wise comparison, and the weights are the principle eigenvector of the pair-wise comparison matrix (Saaty, 1980). This comparison can be done by either an individual or a group. To obtain the suitability measures to be used in the model, another set of factors are needed: the trade-off weights of the alternative land uses so that more important land uses could occupy the most suitable sites. When these weights are determined as either a priory or again using pair-wise comparison, the composite suitability indexes are normalized so that the weights could trade off the values in the same interval. Then, the scaled transformation representing the net benefit over the minimum is defined as follows (Carver, 1991; Hanink \& Cromley, 1998):

$$
S_{i j}^{\prime}=W_{j} \frac{S_{i j}-\min _{i} S_{i j}}{\max _{i} S_{i j}-\min _{i} S_{i j}} .
$$

In summary, to be able to operationalize the general assignment model, one needs to estimate the measurements of potential criteria for each land use as (i) the suitability scalars of the parcels for the land uses with respect to the suitability criterion, (ii) the combinatorial weights of suitability criteria for each land use and for each parcel and (iii) the trade-off weights for land-use types in the models.

\section{Description of Study Area}

As it can be seen from Figure 1, Cesme is a county town of the Izmir Province in Turkiye, and located at the far west corner of the peninsula called with the same name. It is a 
summer resort of Turkey for the nationals and a very attractive destination for international tourism. For this reason, there are big differences in the population of the city during the winters and summers. The population of the city is around 30,000 in the winters, while it can reach up to 150,000 even 200,000 with daily visitors for seasonal attractions in the summers. This mass demand of tourism has inevitably put a very high pressure on the fragile assets that include geo-thermal resources, very pristine bays, sceneries, coast lines, archaeological sites and historical urban architecture. Construction demand for resort houses and tourism facilities with varying type, quality and magnitudes in these sensitive areas has been very high to increase the economic benefit.

Starting in 1990s, the Regional Conservation Council has declared the first conservation areas within the city. According to the Turkish Conservation Law (natural or archaeological), conservation areas are classified into three groups: the first-degree areas shall be strictly conserved. Any type of construction is strictly forbidden; only recreational activities can take place in these areas. The second-degree conservation areas can only be allocated to recreational, forestation or tourism activities. The third-degree areas, however, can be allocated to every type of uses. However, the construction densities and architectural designs may be controlled by the regional conservation councils. When the first conservation was ruled in 1992, the total area of conservation was 1.819 ha, with only 486 ha of it being first degree. As it can be seen in Table 1, a drastic increase and exaggeration in all classes, especially in the first-degree natural conservation areas, were ruled by the council in 1995 .

Obviously, the environmentalist groups played an active role in this decision. The decision caused many arguments that the council had made their decision based on their emotions, and that they did not have any analytical basis. Since then, the conservation schemes were modified twice. In these modifications, even though the total area of conservation was not decreased, the share of the first-degree conservation areas was gradually decreased by half. These modifications were pushed by the investors in the city. This time, the environmentalists were the complaining side. The spatial configurations of the conservation schemes over time are presented in Figure 2. Recently, a new planning effort in the city has ignited the same discussions about the geographical extension and classification of the conservation areas. Coming up with a somewhat rational answer to these discussions is the primary motivation of this paper.

The area covering the central city is approximately 9.450 ha. This area is also our study area, and it will be covered by a new plan. The land-use types and their respective surface

Table 1. Conservation schemes for different years

\begin{tabular}{lrrrr}
\hline & \multicolumn{4}{c}{ Conservation schemes (ha) } \\
\cline { 2 - 5 } & 1992 & 1995 & 1998 & 2007 \\
\hline First-degree natural & 486 & 4360 & 3458 & 1943 \\
Second-degree natural & 1072 & 1721 & 1439 & 1785 \\
Third-degree natural & & 791 & 2077 & 3075 \\
First-degree archaeological & & 99 & 42 & 41 \\
Third-degree archaeological & 212 & 115 & 127 & 141 \\
Urban conservation & 49 & & 123 & 20 \\
Total conservation & 1819 & 7085 & 7265 & 7005 \\
\hline
\end{tabular}




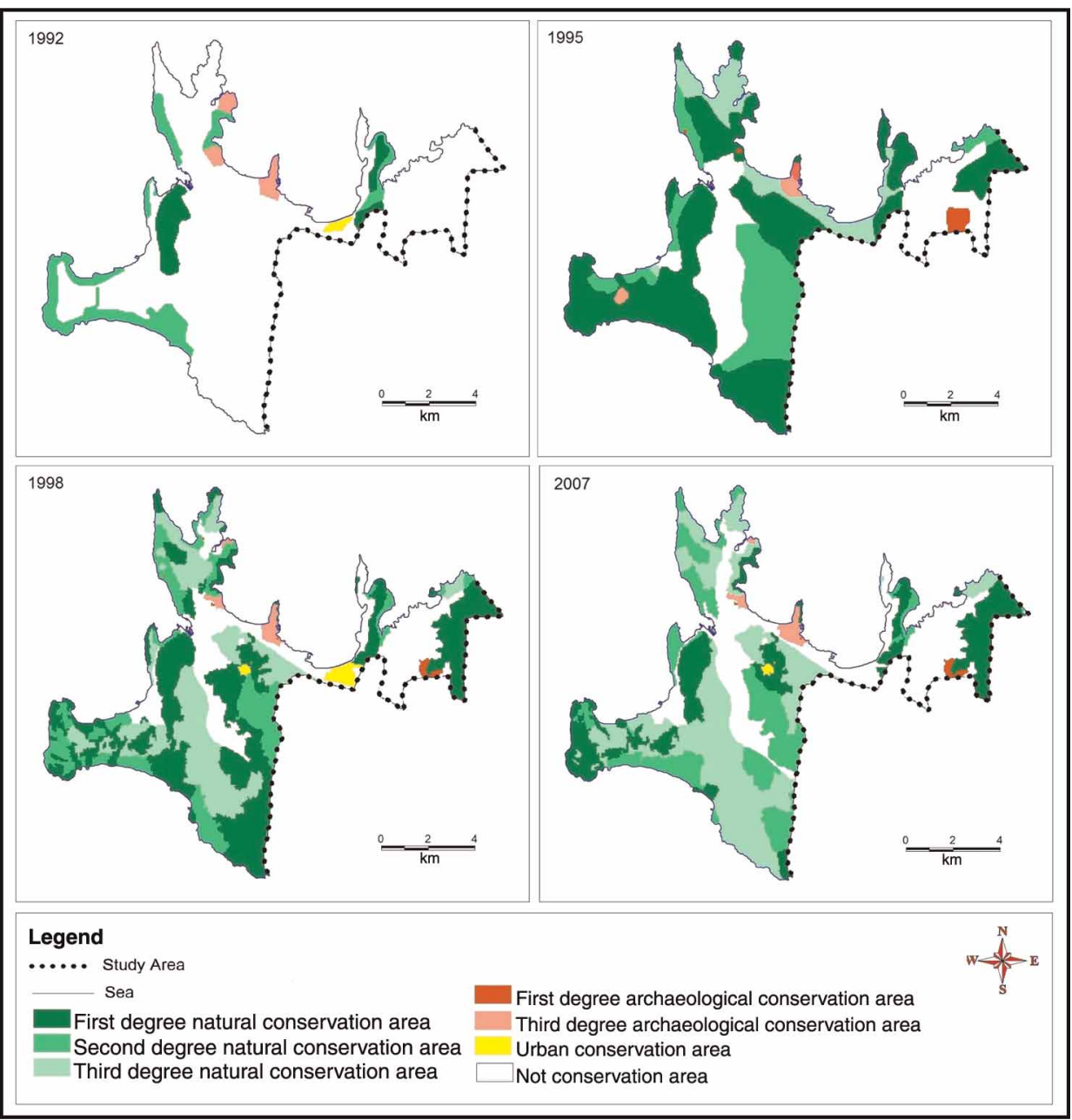

Figure 2. Conservation areas over years

areas are resolved by the planners, the Cesme City Council and the locals. For modelling purposes, these land uses are combined into nine corresponding supra-groups as presented in Table 2. The reason for this combination was that the pair-wise comparison technique could produce a consistent result when the compared alternatives were $7 \pm 2$ (Saaty, 1980). The total area of the land uses that was included in the model was 9.068 ha. Approximately 390 ha were kept out of the model since they were built-up areas and infrastructure facilities. This new plan would accommodate approximately 180,000 residing people in future.

\section{Preparation of Required Data}

Two major groups of tasks were completed during data acquisition: (i) preparing and digitizing thematic maps that represent suitability criteria; and (ii) conducting the surveys to 
Table 2. Future land-use amounts and corresponding number of grid parcels

\begin{tabular}{lcc}
\hline Land uses & Area (ha) & Number of parcels \\
\hline Residential development area & 184 & 735 \\
Commerce and administrative area & 105 & 419 \\
Tourism area & 680 & 2.716 \\
Preferential tourism and residential & 1.644 & 6.576 \\
Thermal tourism & 279 & 1.116 \\
Public facilities & 106 & 424 \\
Recreation area & 891 & 3.564 \\
Agricultural area & 1.887 & 7.548 \\
Forestation & 2.762 & 11.048 \\
Unusable areas & 531 & 2.124 \\
Total & 9.068 & 36.270 \\
\hline
\end{tabular}

determine (a) the suitability evaluation criteria for each land use, (b) the combinatorial weights of criteria for each land use and (c) the trade-off weights for each land use. As stated earlier, nine supra-groups of land uses were included in the model, and all the relevant criteria were obtained accordingly.

At the beginning, a survey was conducted to determine the relevant criteria for each land use even though it was possible to obtain them from the literature (Malczewski, 1999). Since the determination of suitability criteria might involve some technical aspect, 20 city planners who were familiar with Cesme from several universities, different municipalities and some other local government agencies in Izmir were chosen as the participants of the survey. The survey was conducted in two stages. In the first stage, a questionnaire including 18 potential criteria was mailed to the participants, and they were asked to score the relevance of each criterion to each land use between 1 and 5, with 1 being counter relevant and 5 being very important. In the second stage, descriptive statistics of the first-stage questionnaire and an analysis were sent to the participants, and they were asked to revise their previous answer in accordance with the results of the first stage if they wanted. Their revised answers in the second stage were statistically analysed. A criterion with a mean value equal to or higher than 3 was deemed as important for the respective land use.

In this way, the slope, ownership of the property (i.e. private versus public), quality of the soil for agricultural use, geological formation, the degree of conservation, existing land use, aspect of the land, visibility of sea and location with respect to the existing potable water dam were determined as important site factors. Among them, only quality of the soil appeared to be important for all land uses. The degree of conservation was also important for all, except for agriculture. Each factor was not necessarily important for every land-use type. Concerning situational factors, proximity to a highway, to a collector road, to the entrance of a motorway, to Cesme city centre, to a residential district, to the sea, to a beach, and to a thermal spring and distance to a fault line were found as the relevant accessibility factors. The proximity to the motorway entrance was not an important criterion to any land use. Proximity to a collector road and the distance to a fault line were the other two important criteria for almost all land uses. The selected criteria and their relevance to the land uses are presented in Table 3. 
Table 3. Selection of evaluation criteria

\begin{tabular}{|c|c|c|c|c|c|c|c|c|c|c|}
\hline & & $\begin{array}{c}\text { Residential } \\
\text { development }\end{array}$ & $\begin{array}{l}\text { Commerce and } \\
\text { administrative }\end{array}$ & Tourism & $\begin{array}{c}\text { Preferential } \\
\text { tourism and } \\
\text { residential }\end{array}$ & $\begin{array}{l}\text { Thermal } \\
\text { tourism }\end{array}$ & $\begin{array}{c}\text { Public } \\
\text { establishment }\end{array}$ & Recreation & Agricultural & Forestation \\
\hline \multirow{9}{*}{$\begin{array}{l}\text { Site } \\
\text { factors }\end{array}$} & Slope & $\checkmark$ & $\checkmark$ & $\checkmark$ & $\checkmark$ & $\checkmark$ & $\checkmark$ & & & \\
\hline & $\begin{array}{l}\text { Ownership of } \\
\text { property }\end{array}$ & $\checkmark$ & $\checkmark$ & $\checkmark$ & $\checkmark$ & $\checkmark$ & $\checkmark$ & $\checkmark$ & & $\checkmark$ \\
\hline & Quality of soil & $\checkmark$ & $\checkmark$ & $\checkmark$ & $\checkmark$ & $\checkmark$ & $\checkmark$ & $\checkmark$ & $\checkmark$ & $\checkmark$ \\
\hline & Geological structure & $\checkmark$ & $\checkmark$ & $\checkmark$ & $\checkmark$ & $\checkmark$ & $\checkmark$ & & & \\
\hline & Conservation degree & $\checkmark$ & $\checkmark$ & $\checkmark$ & $\checkmark$ & $\checkmark$ & $\checkmark$ & $\checkmark$ & & $\checkmark$ \\
\hline & Existing land use & $\checkmark$ & $\checkmark$ & $\checkmark$ & $\checkmark$ & $\checkmark$ & $\checkmark$ & $\checkmark$ & $\checkmark$ & $\checkmark$ \\
\hline & Aspect & $\checkmark$ & & $\checkmark$ & $\checkmark$ & $\checkmark$ & & $\checkmark$ & & \\
\hline & Visibility of sea & $\checkmark$ & & $\checkmark$ & $\checkmark$ & & & $\checkmark$ & & \\
\hline & $\begin{array}{l}\text { Location with } \\
\text { respect to potable } \\
\text { water dam }\end{array}$ & $\checkmark$ & $\checkmark$ & $\checkmark$ & $\checkmark$ & $\checkmark$ & $\checkmark$ & $\checkmark$ & & \\
\hline \multirow[t]{9}{*}{$\begin{array}{r}\text { Situation } \\
\text { factors }\end{array}$} & $\begin{array}{l}\text { Proximity to } \\
\text { highway }\end{array}$ & $\checkmark$ & $\checkmark$ & $\checkmark$ & $\checkmark$ & & $\checkmark$ & & & \\
\hline & $\begin{array}{l}\text { Proximity to second- } \\
\text { degree road }\end{array}$ & $\checkmark$ & $\checkmark$ & $\checkmark$ & $\checkmark$ & $\checkmark$ & $\checkmark$ & & & \\
\hline & $\begin{array}{l}\text { Proximity to } \\
\text { motorway } \\
\text { entrance }\end{array}$ & & & & & & & & & \\
\hline & $\begin{array}{l}\text { Proximity to Cesme } \\
\text { city centre }\end{array}$ & $\checkmark$ & $\checkmark$ & & $\checkmark$ & & $\checkmark$ & & & \\
\hline & $\begin{array}{l}\text { Proximity to } \\
\text { residential district }\end{array}$ & $\checkmark$ & $\checkmark$ & & & & $\checkmark$ & & & \\
\hline & Proximity to sea & $\checkmark$ & & $\checkmark$ & $\checkmark$ & & & $\checkmark$ & & \\
\hline & Proximity to beach & $\checkmark$ & & $\checkmark$ & $\checkmark$ & & & & & \\
\hline & $\begin{array}{l}\text { Proximity to thermal } \\
\text { spring }\end{array}$ & & & $\checkmark$ & & $\checkmark$ & & & & \\
\hline & Distance to fault line & $\checkmark$ & $\checkmark$ & $\checkmark$ & $\checkmark$ & $\checkmark$ & $\checkmark$ & & & \\
\hline
\end{tabular}


Upon collecting all the necessary information from the relevant public agencies such as Cesme Municipality, the Directorate of Agriculture, the Directorate of State Hydraulic Works and the others, all the thematic maps were vectorized into a GIS environment (Map Info). These vectors were converted into rasters with a cell size of $50 \mathrm{mt}$ by 50 $\mathrm{mt}$, establishing a total of 36.270 cells (or parcels). The maps of the slope, aspect and visibility to the sea were derived from the digital elevation model generated by digitizing the contour lines. The Vertical Mapper module in MapInfo software has the capability to prepare the slope and aspect maps. However, MapInfo is not yet having the capability to analyse visibility of the sea from each parcel. To achieve such a task, a computer code was written in $\mathrm{C}++$ programming language.

Raster cell values appeared in different ranges and different scales in each thematic map. Values in each raster were split into 2-9 meaningful scaling intervals, and the importance of each scaling interval to each land use was evaluated based on the field observations. The pair-wise comparison could again be a good candidate for this evaluation. In this way, a raw score for each criterion for each land use was obtained: $A_{j k}$ raw score for $j$ th land use and $k$ th criterion map. These raw scores, however, still needed an overall standardization. For this standardization, the formula recommended by Voogd (1983) and Malczewski (1999) as shown in Equation (9) was used

$$
A_{j k}^{\prime}=\frac{A_{j k}-A_{k}^{\min }}{A_{k}^{\max }-A_{k}^{\min }} .
$$

The formula is self-explanatory, and the obtained scores are between 0 and 1 . The estimated suitability scores for each criterion and each land use is presented in Table 4.

The subsequent task was to determine the combinatorial weights for estimating suitability scores as it was stated in Equation 7. To do this, a meeting with a subgroup of initially surveyed planners was organized. In this meeting, the weights were estimated again using pair-wise comparison. In the first round of the meeting, the participants were asked to make their individual pair-wise comparison. In the second round, the weights were decided collectively with agreement. The estimated weights for each criterion with respect to each land use are given in Table 5.

The last piece of information to formulate the mathematical program was the trade-off weights. These weights are the key to land allocation since land uses deemed to be more important should occupy their most suitable sites. At the same time, this is a proxy to the relative valuation of land uses in that city, and it was not an issue of technicality. For this reason, this time, some members of the city council were invited to another meeting instead of the planners. Obviously, each individual in the meeting had personal tradeoff values depending on his/her economic, social and environmental interest. However, formulating a separate mathematical program for each individual will not resolve any issue. Thus, a single set of agreed trade-off values was elaborated in the meeting. The resultant trade-off values are presented in Table 6.

Using these trade-off weights, the standardized suitability scores were estimated using Equation (8). The pair-wise comparison was the main technique for estimating all these weights. As stated earlier, the weights were the principle eigenvector of pair-wise comparison matrices. These matrices and their eigenvectors were estimated with the MATLAB environment. 
Table 4. Standardized suitability scores for each land use and criteria

\begin{tabular}{|c|c|c|c|c|c|c|c|c|c|c|}
\hline Criteria & Category & $\begin{array}{c}\text { Residential } \\
\text { development }\end{array}$ & $\begin{array}{l}\text { Commerce and } \\
\text { administrative }\end{array}$ & Tourism & $\begin{array}{l}\text { Preferential } \\
\text { tourism and } \\
\text { residential }\end{array}$ & $\begin{array}{l}\text { Thermal } \\
\text { tourism }\end{array}$ & $\begin{array}{c}\text { Public } \\
\text { establishment }\end{array}$ & Recreation & Agricultural & Afforestation \\
\hline \multirow[t]{5}{*}{ Slope (\%) } & $0-5$ & 1 & 1 & 1 & 1 & 1 & 1 & & & \\
\hline & $6-10$ & 0.710 & 0.294 & 0.710 & 0.710 & 0.710 & 0.710 & & & \\
\hline & $11-20$ & 0.077 & 0.111 & 0.077 & 0.077 & 0.077 & 0.077 & & & \\
\hline & $21-40$ & 0.022 & 0 & 0.022 & 0.022 & 0.022 & 0.022 & & & \\
\hline & $41-65$ & 0 & 0 & 0 & 0 & 0 & 0 & & & \\
\hline \multirow[t]{6}{*}{ Property } & Private & 1 & 1 & 1 & 1 & 1 & 0.125 & 0 & & 0 \\
\hline & Municipality & 0.378 & 1 & 0.377 & 0.247 & 1 & 0.295 & 1 & & 0.098 \\
\hline & $\begin{array}{l}\text { Treasury and } \\
\text { municipality }\end{array}$ & 0.378 & 1 & 0.377 & 0.247 & 1 & 0.541 & 1 & & 0.156 \\
\hline & Deserted land & 0.378 & 1 & 0.377 & 0.247 & 1 & 1 & 1 & & 0.234 \\
\hline & Treasury & 0.378 & 1 & 0.377 & 0.247 & 1 & 1 & 1 & & 0.234 \\
\hline & Forest & 0 & 0 & 0 & 0 & 0 & 0 & 0.302 & & 1 \\
\hline \multirow[t]{5}{*}{ Quality of soil } & I and II & 0 & 0 & 0 & 0 & 0 & 0 & 0 & 1 & 0 \\
\hline & III & 0 & 0.027 & 0 & 0 & 0 & 0 & 0 & 1 & 0 \\
\hline & IV & 0.208 & 0.147 & 0.159 & 0.207 & 0.207 & 0.207 & 0.231 & 0.428 & 0.190 \\
\hline & V & 0.652 & 0.339 & 0.545 & 0.648 & 0.648 & 0.648 & 0.498 & 0.119 & 0.476 \\
\hline & VI and VII & 1 & 1 & 1 & 1 & 1 & 1 & 1 & 0 & 1 \\
\hline \multirow{7}{*}{$\begin{array}{r}\text { Geological } \\
\text { structure }\end{array}$} & Agglomerate & 1 & 1 & 1 & 1 & 1 & 1 & & & \\
\hline & $\begin{array}{l}\text { Agglomerate and } \\
\text { tuff }\end{array}$ & 1 & 1 & 1 & 1 & 1 & 1 & & & \\
\hline & Limestone & 0.531 & 0.531 & 0.531 & 0.531 & 0.531 & 0.531 & & & \\
\hline & Dolomite & 0.303 & 0.303 & 0.303 & 0.303 & 0.303 & 0.303 & & & \\
\hline & $\begin{array}{l}\text { Clay limestone } \\
\text { marl }\end{array}$ & 0.155 & 0.155 & 0.155 & 0.155 & 0.155 & 0.155 & & & \\
\hline & Alluvium & 0.040 & 0.040 & 0.040 & 0.040 & 0.040 & 0.040 & & & \\
\hline & Talus & 0 & 0 & 0 & 0 & 0 & 0 & & & \\
\hline
\end{tabular}


Table 4. Continued

\begin{tabular}{|c|c|c|c|c|c|c|c|c|c|c|}
\hline Criteria & Category & $\begin{array}{c}\text { Residential } \\
\text { development }\end{array}$ & $\begin{array}{l}\text { Commerce and } \\
\text { administrative }\end{array}$ & Tourism & $\begin{array}{c}\text { Preferential } \\
\text { tourism and } \\
\text { residential }\end{array}$ & $\begin{array}{l}\text { Thermal } \\
\text { tourism }\end{array}$ & $\begin{array}{c}\text { Public } \\
\text { establishment }\end{array}$ & Recreation & Agricultural & Afforestation \\
\hline \multirow{7}{*}{$\begin{array}{l}\text { Degree and type of } \\
\text { conservation }\end{array}$} & First natural & 0 & 0 & 0 & 0 & 0 & 0 & 1 & & 1 \\
\hline & Second natural & 0 & 0 & 0.187 & 0.187 & 0.215 & 0 & 1 & & 0.698 \\
\hline & Third natural & 0.216 & 0.216 & 0.456 & 0.456 & 0.504 & 0.216 & 1 & & 0.284 \\
\hline & $\begin{array}{l}\text { First } \\
\quad \text { archaeological }\end{array}$ & 0 & 0 & 0 & 0 & 0 & 0 & 0 & & 0 \\
\hline & $\begin{array}{l}\text { Third } \\
\text { archaeological }\end{array}$ & 0.229 & 0.226 & 0.477 & 0.477 & 0.533 & 0.229 & 1 & & 0.254 \\
\hline & $\begin{array}{l}\text { Urban } \\
\text { conservation } \\
\text { area }\end{array}$ & 0.394 & 0.339 & 0.456 & 0.456 & 0.041 & 0.394 & 1 & & 0 \\
\hline & $\begin{array}{l}\text { Not conserved } \\
\text { area }\end{array}$ & 1 & 1 & 1 & 1 & 1 & 1 & 1 & & 0.355 \\
\hline \multirow[t]{4}{*}{ Existing land use } & Unsuitable land & 1 & 1 & 1 & 1 & 1 & 1 & 1 & 0.250 & 0.318 \\
\hline & Forest & 0 & 0 & 0 & 0 & 0 & 0 & 0.200 & 0 & 1 \\
\hline & Agriculture & 0.332 & 0.282 & 0.282 & 0.283 & 0.155 & 0.268 & 0.200 & 0 & 0.079 \\
\hline & Others & 0.332 & 0.229 & 0.229 & 0.099 & 0.392 & 0.219 & 0 & 1 & 0 \\
\hline \multirow[t]{4}{*}{ Aspect } & North & 0 & & 0 & 0 & 0 & & 1 & & \\
\hline & West & 0.348 & & 0.348 & 0.348 & 0.348 & & 0 & & \\
\hline & East & 0.348 & & 0.348 & 0.348 & 0.348 & & 0 & & \\
\hline & South & 1 & & 1 & 1 & 1 & & 1 & & \\
\hline \multirow[t]{2}{*}{ Visibility of sea } & Yes & 1 & & 1 & 1 & & & 1 & & \\
\hline & No & 0 & & 0 & 0 & & & 0 & & \\
\hline \multirow{4}{*}{$\begin{array}{l}\text { Location with } \\
\text { respect to } \\
\text { potable water } \\
\text { dam }\end{array}$} & First degree & 0 & 0 & 0 & 0 & 0 & 0 & 0 & & \\
\hline & Second degree & 0 & 0 & 0 & 0 & 0 & 0 & 0 & & \\
\hline & Third degree & 0 & 0 & 0 & 0 & 0 & 0 & 0.442 & & \\
\hline & $\begin{array}{l}\text { Out of protection } \\
\text { belt of dam }\end{array}$ & 1 & 1 & 1 & 1 & 1 & 1 & 1 & & \\
\hline \multirow{6}{*}{$\begin{array}{l}\text { Proximity to } \\
\text { highway (m) }\end{array}$} & $0-100$ & 1 & 1 & 1 & 0.504 & & 1 & & & \\
\hline & $101-250$ & 0.509 & 0.367 & 0.730 & 1 & & 0.580 & & & \\
\hline & $251-500$ & 0.230 & 0.171 & 0.339 & 0.546 & & 0.312 & & & \\
\hline & $501-1000$ & 0.079 & 0.072 & 0.116 & 0.162 & & 0.147 & & & \\
\hline & $1001-2000$ & 0.029 & 0 & 0.041 & 0.050 & & 0.050 & & & \\
\hline & $2000+$ & 0 & 0 & 0 & 0 & & 0 & & & \\
\hline
\end{tabular}




\begin{tabular}{|c|c|c|c|c|c|c|c|c|}
\hline \multirow{6}{*}{$\begin{array}{l}\text { Proximity to } \\
\text { second-degree } \\
\text { road }(\mathrm{m})\end{array}$} & $0-100$ & 1 & 1 & 1 & 1 & 1 & 1 & \\
\hline & $101-250$ & 0.396 & 0.367 & 0.564 & 0.396 & 0.367 & 0.580 & \\
\hline & $251-500$ & 0.214 & 0.171 & 0.312 & 0.214 & 0.171 & 0.312 & \\
\hline & $501-1000$ & 0.102 & 0.069 & 0.144 & 0.102 & 0.069 & 0.147 & \\
\hline & $1001-2000$ & 0.037 & 0.002 & 0.052 & 0.037 & 0.002 & 0.050 & \\
\hline & $2000+$ & 0 & 0 & 0 & 0 & 0 & 0 & \\
\hline \multirow{5}{*}{$\begin{array}{l}\text { Proximity to } \\
\text { centrum of } \\
\text { Çeşme (m) }\end{array}$} & $0-1000$ & 1 & 1 & & 1 & & 1 & \\
\hline & $1001-1500$ & 0.349 & 0.534 & & 0.349 & & 0.537 & \\
\hline & $1501-2000$ & 0.165 & 0.254 & & 0.165 & & 0.262 & \\
\hline & $2001-3000$ & 0.082 & 0.094 & & 0.082 & & 0.122 & \\
\hline & $3000+$ & 0 & 0 & & 0 & & 0 & \\
\hline \multirow{5}{*}{$\begin{array}{l}\text { Proximity to } \\
\text { residential } \\
\text { district }(\mathrm{m})\end{array}$} & $0-250$ & 1 & 1 & & & & 1 & \\
\hline & $251-500$ & 0.349 & 0.365 & & & & 0.349 & \\
\hline & $501-1000$ & 0.165 & 0.178 & & & & 0.165 & \\
\hline & $1001-2000$ & 0.082 & 0.064 & & & & 0.082 & \\
\hline & $2000+$ & 0 & 0 & & & & 0 & \\
\hline \multirow{7}{*}{$\begin{array}{l}\text { Proximity to sea } \\
\quad(\mathrm{m})\end{array}$} & $0-50$ & 0 & & 0 & 0 & & & 1 \\
\hline & $51-100$ & 0 & & 0 & 0 & & & 1 \\
\hline & $101-200$ & 1 & & 1 & 1 & & & 0.561 \\
\hline & $201-500$ & 0.428 & & 0.672 & 0.777 & & & 0.309 \\
\hline & $501-1000$ & 0.234 & & 0.426 & 0.535 & & & 0.141 \\
\hline & $1001-2000$ & 0.109 & & 0.176 & 0.395 & & & 0.056 \\
\hline & $2000+$ & 0.042 & & 0.064 & 0.188 & & & 0 \\
\hline \multirow{7}{*}{$\begin{array}{l}\text { Proximity to beach } \\
\text { (m) }\end{array}$} & $0-50$ & 0 & & 0 & 0 & & & \\
\hline & $51-100$ & 0 & & 0 & 0 & & & \\
\hline & $101-200$ & 1 & & 1 & 1 & & & \\
\hline & $201-500$ & 0.536 & & 0.737 & 0.738 & & & \\
\hline & $501-1000$ & 0.261 & & 0.438 & 0.487 & & & \\
\hline & $1001-2000$ & 0.101 & & 0.214 & 0.287 & & & \\
\hline & $2000+$ & 0.027 & & 0.084 & 0.168 & & & \\
\hline \multirow{5}{*}{$\begin{array}{l}\text { Proximity to } \\
\text { thermal spring } \\
\text { (m) }\end{array}$} & $0-250$ & & & 1 & & 1 & & \\
\hline & $251-500$ & & & 0.510 & & 0.596 & & \\
\hline & $501-1000$ & & & 0.248 & & 0.404 & & \\
\hline & $1001-2000$ & & & 0.093 & & 0.143 & & \\
\hline & $2000+$ & & & 0 & & 0 & & \\
\hline \multirow{5}{*}{$\begin{array}{l}\text { Distance to fault } \\
\text { line }(\mathrm{m})\end{array}$} & $0-250$ & 0 & 0 & 0 & 0 & 0 & 0 & \\
\hline & $251-500$ & 0.117 & 0.132 & 0.117 & 0.117 & 0.132 & 0.132 & \\
\hline & $501-1000$ & 0.271 & 0.301 & 0.271 & 0.271 & 0.301 & 0.301 & \\
\hline & $1001-2000$ & 0.463 & 0.560 & 0.463 & 0.463 & 0.560 & 0.560 & \\
\hline & $2000+$ & 1 & 1 & 1 & 1 & 1 & 1 & \\
\hline
\end{tabular}


Table 5. Combinatorial weights of the selected criteria

\begin{tabular}{|c|c|c|c|c|c|c|c|c|c|c|}
\hline & & $\begin{array}{c}\text { Residential } \\
\text { development }\end{array}$ & $\begin{array}{l}\text { Commerce and } \\
\text { administrative }\end{array}$ & Tourism & $\begin{array}{l}\text { Preferential } \\
\text { tourism and } \\
\text { residential }\end{array}$ & $\begin{array}{l}\text { Thermal } \\
\text { tourism }\end{array}$ & $\begin{array}{c}\text { Public } \\
\text { establishment }\end{array}$ & Recreation & Agricultural & Afforestation \\
\hline \multirow{9}{*}{$\begin{array}{l}\text { Site } \\
\text { factors }\end{array}$} & Slope & 0.025 & 0.020 & 0.014 & 0.02 & 0.020 & 0.03 & & & \\
\hline & Property & 0.011 & 0.020 & 0.014 & 0.008 & 0.020 & 0.087 & 0.288 & & 0.187 \\
\hline & Quality of soil & 0.025 & 0.061 & 0.04 & 0.084 & 0.060 & 0.030 & 0.106 & 0.875 & 0.063 \\
\hline & $\begin{array}{l}\text { Geological } \\
\text { structure }\end{array}$ & 0.025 & 0.122 & 0.067 & 0.094 & 0.11 & 0.087 & & & \\
\hline & $\begin{array}{l}\text { Conservation } \\
\text { degree }\end{array}$ & 0.191 & 0.13 & 0.117 & 0.130 & 0.126 & 0.161 & 0.120 & & 0.563 \\
\hline & Existing land use & 0.074 & 0.02 & 0.033 & 0.020 & 0.021 & 0.016 & 0.097 & 0.125 & 0.187 \\
\hline & Aspect & 0.025 & & 0.069 & 0.020 & 0.021 & & 0.114 & & \\
\hline & Visibility of sea & 0.016 & & 0.069 & 0.037 & & & 0.054 & & \\
\hline & $\begin{array}{l}\text { Location with } \\
\text { respect to } \\
\text { potable water } \\
\text { dam }\end{array}$ & 0.108 & 0.130 & 0.077 & 0.085 & 0.122 & 0.088 & 0.054 & & \\
\hline \multirow[t]{8}{*}{$\begin{array}{l}\text { Situation } \\
\text { factors }\end{array}$} & $\begin{array}{l}\text { Proximity to } \\
\text { highway }\end{array}$ & 0.039 & 0.025 & 0.017 & 0.023 & & 0.042 & & & \\
\hline & $\begin{array}{l}\text { Proximity to } \\
\text { second-degree } \\
\text { road }\end{array}$ & 0.104 & 0.07 & 0.053 & 0.082 & 0.100 & 0.015 & & & \\
\hline & $\begin{array}{l}\text { Proximity to the } \\
\text { city centre of } \\
\text { Çeşme }\end{array}$ & 0.088 & 0.137 & & 0.078 & & 0.12 & & & \\
\hline & $\begin{array}{l}\text { Proximity to } \\
\text { residential } \\
\text { district }\end{array}$ & 0.039 & 0.132 & & & & 0.12 & & & \\
\hline & Proximity to sea & 0.088 & & 0.109 & 0.082 & & & 0.167 & & \\
\hline & Proximity to beach & 0.039 & & 0.109 & 0.078 & & & & & \\
\hline & $\begin{array}{l}\text { Proximity to } \\
\text { thermal spring }\end{array}$ & & & 0.103 & & 0.200 & & & & \\
\hline & $\begin{array}{l}\text { Distance to fault } \\
\text { line }\end{array}$ & 0.103 & 0.133 & 0.109 & 0.159 & 0.200 & 0.204 & & & \\
\hline
\end{tabular}


Table 6. Trade-off weights

\begin{tabular}{lcccc}
\hline & \multicolumn{4}{c}{ Weights } \\
\cline { 2 - 5 } & $\begin{array}{c}\text { Economic } \\
\text { benefit }\end{array}$ & $\begin{array}{c}\text { Social } \\
\text { benefit }\end{array}$ & $\begin{array}{c}\text { Environmental } \\
\text { benefit }\end{array}$ & $\begin{array}{c}\text { Trade-off } \\
\text { weight }\end{array}$ \\
\hline $\begin{array}{l}\text { Residential development } \\
\text { Commerce and }\end{array}$ & 0.077 & 0.038 & 0.026 & 0.047 \\
$\quad$ administrative & 0.033 & 0.022 & 0.026 & 0.027 \\
$\begin{array}{l}\text { Tourism } \\
\text { Preferential tourism and }\end{array}$ & 0.268 & 0.079 & 0.083 & 0.141 \\
$\quad$ residential & 0.252 & 0.079 & 0.026 & 0.116 \\
$\begin{array}{l}\text { Thermal tourism } \\
\text { Public establishment }\end{array}$ & 0.268 & 0.079 & 0.108 & 0.150 \\
$\begin{array}{l}\text { Recreation } \\
\text { Agricultural }\end{array}$ & 0.021 & 0.226 & 0.026 & 0.086 \\
Forestation & 0.021 & 0.28 & 0.235 & 0.18 \\
\hline
\end{tabular}

\section{Empirical Land Assignment and Results}

As stated earlier, the main motivation for this study was to produce a more rational answer to a subjectively discussed question: namely, given four alternative conservation schemes, nine land-use types and their respective predetermined demand levels, which one of the conservation schemes would maximize the total urban benefit? To find an answer, the mathematical formulation given by Equations (1)-(4) was used. During data preparation, four different sets of suitability scores were computed for each conservation schemes since the changing schemes would eventually change the suitability scores of land parcels for certain land uses. With these different suitability scores, the mathematical program was run four times, one for each scheme. Since this is a maximization problem, the scheme achieving the highest objective function value would then mean the most preferable scheme in terms of "conservation and usage equilibrium", giving an explicit answer to our research question.

There were 36.270 parcels, each one of them being a decision variable in our program. The number of parcels expressed in both Equations (2) and (4) was 36.270 for each, and it was nine in Equation 3. The right-hand side values, level of demand, for these equations are given in Table 2 as the number of parcels. The programs were again estimated in the MATLAB environment.

Change in total city/social benefits with respect to changes in conservation schemes is shown in Figure 3. According to the results, the highest objective value is associated with the conservation schemes ruled in 1998, indicating a more acceptable alternative, given local people's perception and valuations. The objective function value was the lowest in 1992 when the conservations geography was real low. Extending the coverage of conservation increased the value of the objective function in 1995. Even though the coverage of the first-degree conservation was decreased in 1998, the value of the objective increased, implying that the scheme in 1995 was over-conserving. In 2007, while the amount of the first-degree conservation was further decreased, the value of objective function decreased, indicating under-conservation for the first-degree conservation areas. 


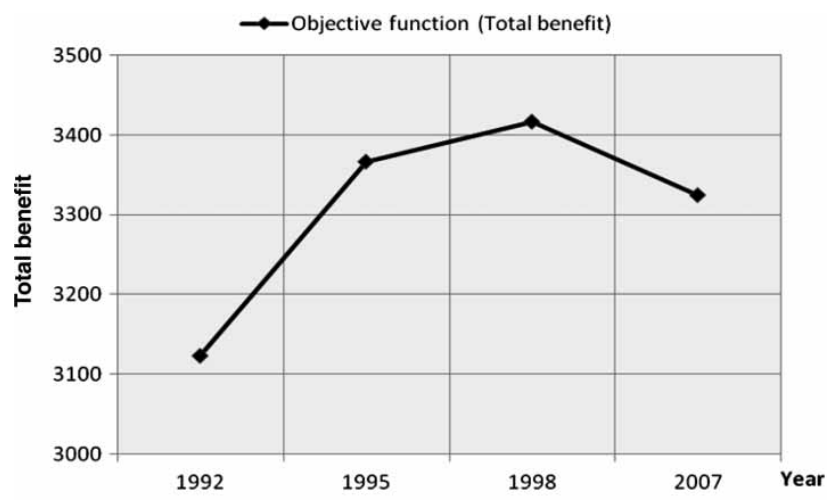

Figure 3. Change in total benefit

Shadow prices associated with land-use demand constraints also reflect the changes in conservation schemes as shown in Figure 4. All shadow prices, except those for forestation, were the highest for the scheme of 1992. The shadow prices of forestation, recreation and agriculture either increased or did not change, but the shadow prices of other land uses decreased in 1995 in comparison with those for 1992. In 1998, the shadow prices of forestation, recreation and agriculture decreased, while the shadow prices of the others either increased or did not change. In 2007, shadow prices of recreation and forestation decreased and those of others did not change. In summary, it is possible to say that the shadow prices of forestation, recreation and agriculture were positively affected by the increase in natural conservation areas. On the other hand, the increase in the natural conservation areas decreased the shadow prices of other land uses with varying amounts.

As a general comment, it is possible to say that the shadow prices were not changed drastically except for the forestation since both total area of planning (i.e. number of decision variables) and the right-hand side of land-use constraints remained unchanged. In any case, all being positive indicates that all the land uses are positively valued since the shadow prices associated with the resource constraints indicate the amount of increase in the objective function when one unit of that resource is increased.
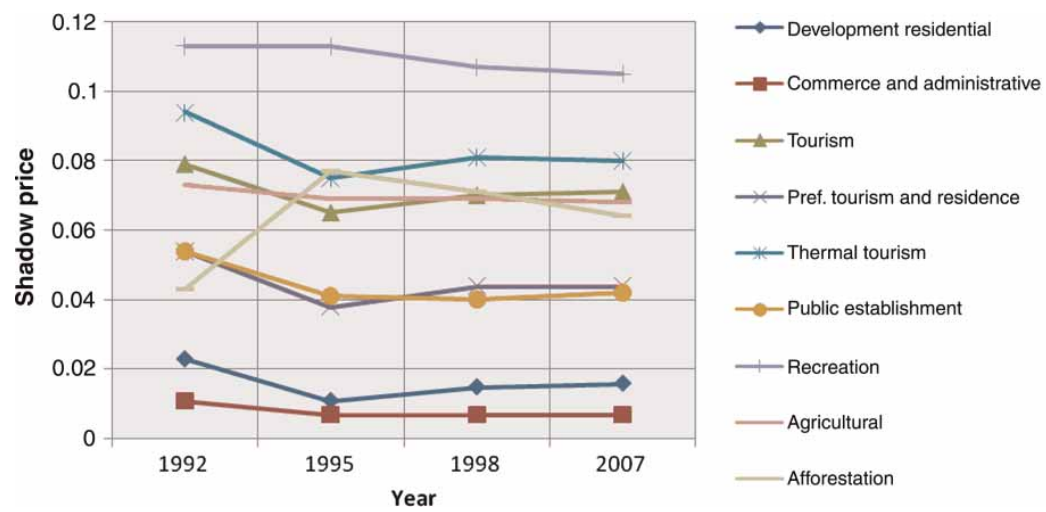

Figure 4. Shadow prices of each land use for each year's conservation scheme 
Using computer outputs for the mathematical program, optimum assignments for each year are depicted and presented in Figure 5. The outputs show that any change in boundary, degree and type of the conservation areas considerably affects the land-use allocation pattern. The allocation of agriculture is not affected like the other land uses since the conservation scheme was not a criterion for allocation of agriculture, and agriculture had a high trade-off weight. However, it is possible to say that the allocations of the other land uses were affected from changing conservation decisions. The first-degree natural conservation areas were assigned only to forestation or recreation, while the seconddegree natural conservation areas were assigned to tourism, recreation or forestation

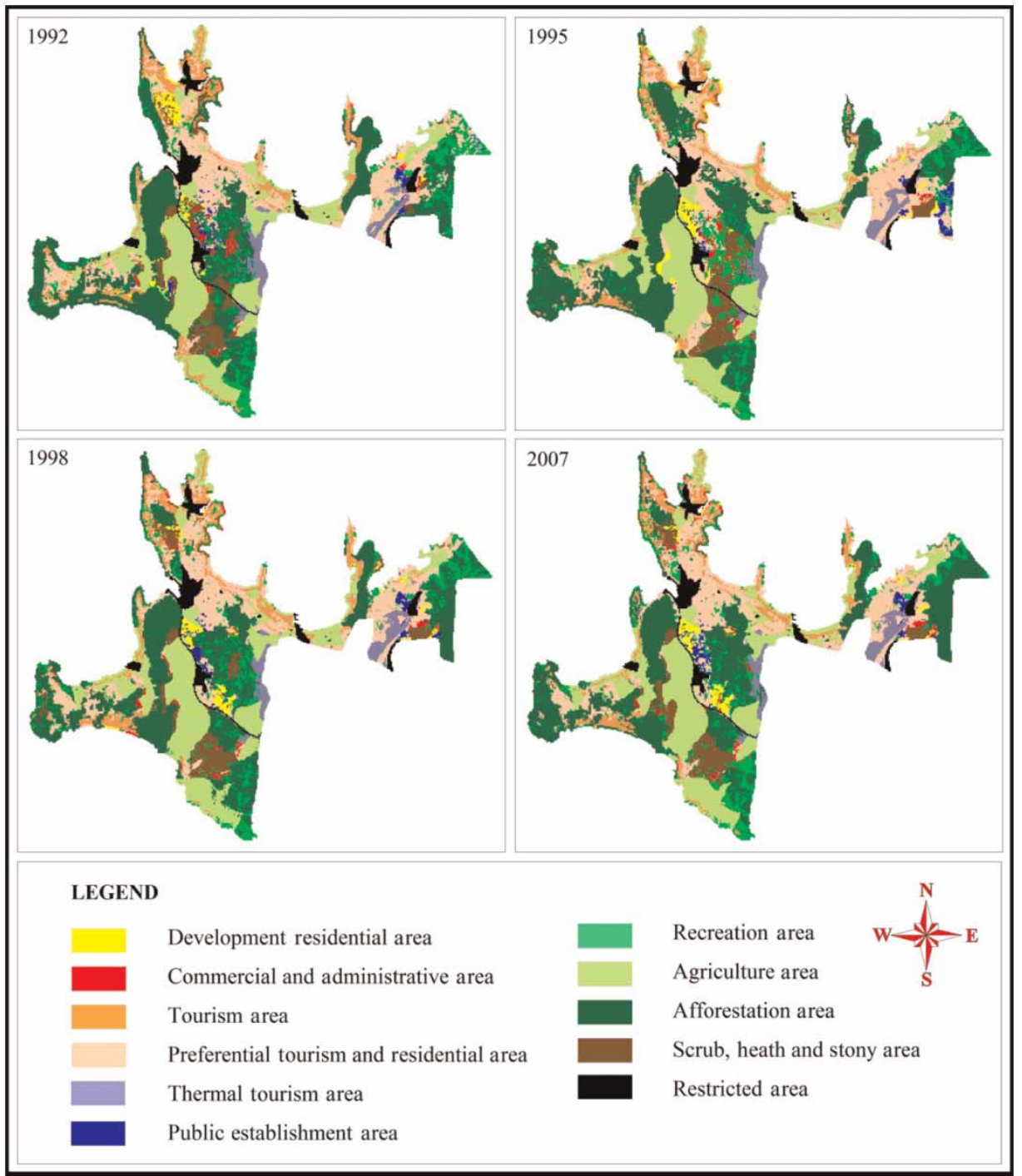

Figure 5. Optimum land-use allocations by the mathematical program 
land for the 1992, 1998 and 2007 conservation schemes. In 1995, the first-degree natural conservation areas were generally assigned to tourism even though it was not legally possible. The second-degree natural conservation areas were assigned to preferential tourism and residence, and the first-degree archaeological areas were assigned to tourism and residence. Obviously, this result was interesting, showing that over-conservation may result in legal violations since it violates the rationality.

Another standard output of the computer for the formulation was the shadow prices associated with the decision variables (i.e. site values of the parcels), and they are also depicted in Figure 6. The prices were expressed in the same interval and they were comparable. It is possible to say that the shadow prices in 1992 were generally lower than the others since the coverage of conservation was the lowest. In 1995, almost all areas were announced as either naturally or archaeologically conserved, leading to the highest prices in unconserved areas. These areas were mostly agricultural lands at the south of the town centre. While the aim was to conserve Cesme from excessive construction, an extensive conservative decision, this time, caused a pressure on agricultural land, and endangered another natural resource. In 1998, changing conservation areas decreased the pressure on the agricultural land. In all the schemes, the shadow prices of parcels along the coast were generally high as expected.

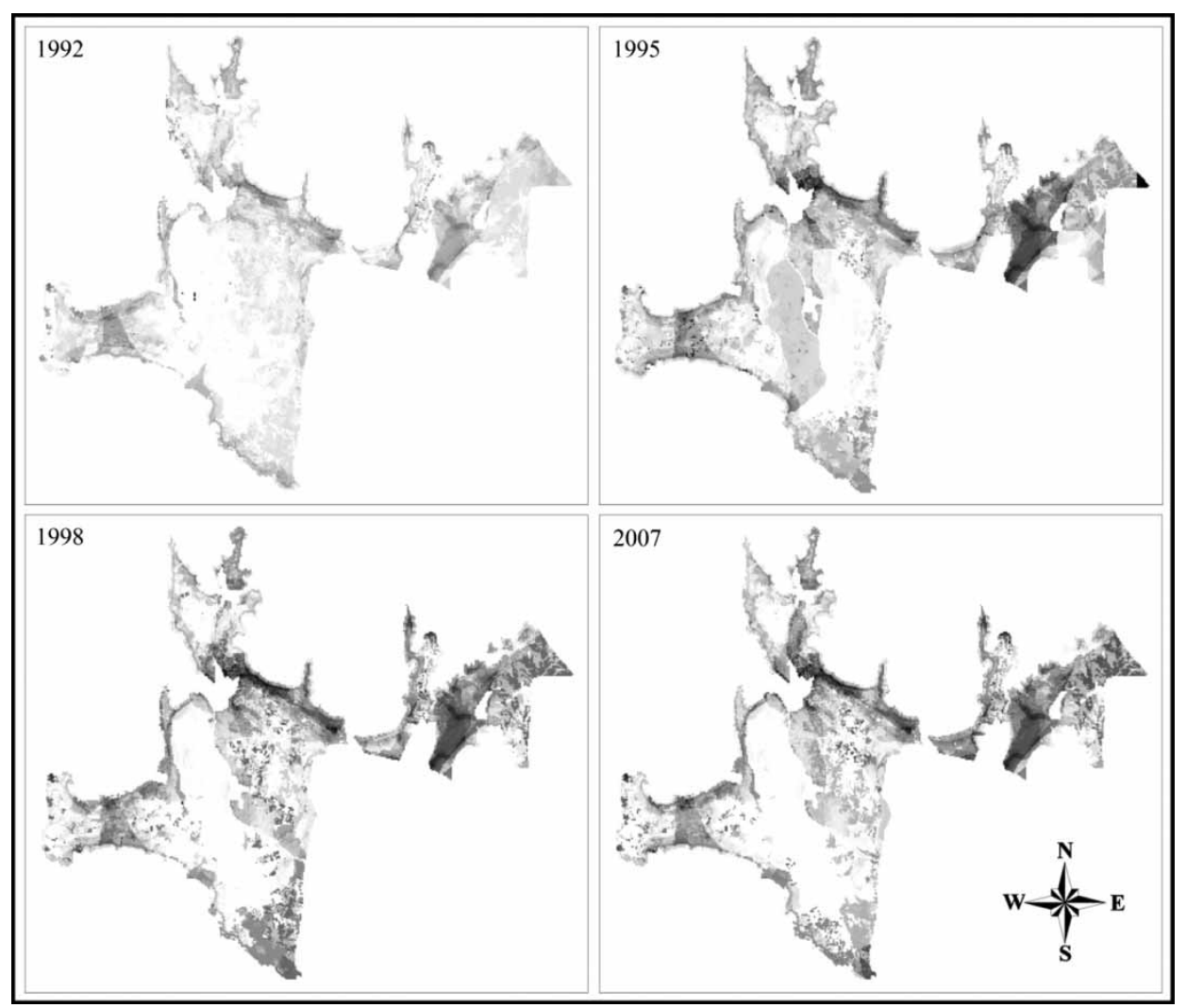

Figure 6. Spatial distribution of shadow prices (darker grey indicates higher prices) 


\section{Conclusion}

This empirical study has shown that the analytical approach as a combination of GIS and MCDM technique as suggested by Hanink and Cromley (1998) can be used in answering argumentative practical and professional issues. As an example of possible usage of the technique, it was possible to determine the optimum spatial coverage of environmental conservation in an urban area, given people's implicit valuation of economically beneficial and non-beneficial usages, and the expected demand level of each usage.

Using its inherent abilities, this technique can be successfully employed in some other practical areas of urban land-use planning. Most important of them would be to determine the optimum level of land uses, especially that of urban facilities. In some countries, there might be minimum levels of certain urban facilities set by legal codes as in Turkey. Since there is no explicit price for these usages, these minimum per capita requirements are determined subjectively, and they are uniformly enforced across all cities within the country. This technique may be a very useful tool to analyse such requirements via the resource shadow prices. If equalities in the resource constraints are relaxed as greater or equal to legally enforced level, the model will increase these land uses up to a level where shadow prices associated with these land uses are zero, meaning that the citywide utility obtained from that specific land use is satisfied, and thus a legal code might be set at that point. This implementation of the technique certainly stands as a future research direction. Furthermore, given the constraints, this technique produces the best allocation of land uses and their respective site and resource shadow prices. These optimum-level shadow prices may successfully be used for estimating the total price of deviation from the optimum for each plan alternative.

Beyond these, there might be many other minor uses of the technique depending on the expectations. All potential uses of the model establish future research direction in evaluation of the empirical performance of MCDM and GIS combining techniques. However, it should be kept in the mind that the technique is very sensitive to the valuation to the respondents' interest. For this reason, selection of the respondents when conducting the required surveys to determine suitability scores and their respective weights should include a fair representation of the existing interest groups within the city at stake.

\section{References}

Aerts, J. C. J. H. \& Heuvelink, G. B. M. (2002) Using simulated annealing for resource allocation, International Journal of Geographical Information Science, 16(6), pp. 571-587.

Aerts, J. C. J. H., Eisinger, E., Heuvelink, G. B. M. \& Stewart, T. J. (2003) Using linear integer programming for multi-site land-use allocation, Geographical Analysis, 35(2), pp. 148-169.

Bammi, D. \& Bammi, D. (1979) Development of a comprehensive land use plan by means of a multiple objective mathematical programming model, Interface, 9(2), pp. 50-63.

Banai, R. (2005) Land resource sustainability for urban development: Spatial decision support system prototype, Environmental Management, 36(2), pp. 282-296.

Barr, J. L. (1973) Tiebout models of community structure, Papers of the Regional Science Association, 30(1), pp. $15-33$.

Bodini, A. \& Giavelli, G. (1992) Multicriteria analysis as a tool to investigate compatibility between conservation and development on Salina Island, Aeolian Archipelago, Italy, Environmental Management, 16(5), pp. 633-652.

Carver, S. (1991) Integrating multi-criteria evaluation with geographical information systems, International Journal of Geographical Information Systems, 5(3), pp. 321-339. 
Cheng, S., Chan, C. W. \& Huang, G. H. (2003) An integrated multi-criteria decision analysis and inexact mixed integer linear programming approach for solid waste management, Engineering Applications of Artificial Intelligence, 16(5-6), pp. 543-554.

Chuvieco, E. (1993) Integration of linear programming and GIS for land-use modeling, International Journal of Geographical Information Systems, 7(6), pp. 71-83.

Cromley, J. R. \& Hanink, D. M. (1999) Coupling land-use allocation models with raster GIS, Journal of Geographical Systems, 1(2), pp. 137-153.

Cromley, J. R. \& Hanink, D. M. (2003) Scale-independent land-use allocation modeling in raster GIS, Cartography and Geographic Information Science, 30(4), pp. 343-350.

Dai, F. C., Lee, C. F. \& Zhang, X. H. (2001) GIS-based geo-environmental evaluation for urban land-use planning: A case study, Engineering Geology, 61(4), pp. 257-271.

Dokmeci, V. F., Cagdas, G. \& Tokcan, S. (1993) Multiobjective land-use planning model, Journal of Urban Planning and Development, 119(1), pp. 15-22.

Eastman, J. R., Jin, W., Kyem, P. A. K. \& Toledano, J. (1995) Raster procedures for multi-criteria/multiobjective decisions, Photogrammetric Engineering \& Remote Sensing, 61(5), pp. 539-547.

Gabriel, S. A., Faria, J. A. \& Moglen, G. E. (2006) A multiobjective optimization approach to smart growth in land development, Socio-Economic Planning Sciences, 40(3), pp. 212-248.

Gilbert, K. C., Holmes, D. D. \& Rosenthal, R. E. (1985) A multiobjective discrete optimization model for land allocation, Management Science, 31(12), pp. 1509-1522.

Grabaum, R. \& Meyer, B. C. (1998) Multicriteria optimization of landscape using GIS-based functional assessments, Landscape and Urban Planning, 43(1), pp. 21-34.

Hall, P. (Ed.) (1966) Von Thünen's Isolated State (English translation by C. M. Wartenberg, with an introduction by the editor) (London: Pergamon Press).

Hanink, D. \& Cromley, R. G. (1998) Land-use allocation in the absence of complete market values, Journal of Regional Science, 38(3), pp. 465-480.

Joerin, F., Theriault, M. \& Musy, A. (2001) Using GIS and outranking multicriteria analysis for land-use suitability assessment, International Journal of Geographical Information Science, 15(2), pp. 153-174.

Ligmann-Zielinska, A., Church, R. L. \& Jankowski, P. (2008) Spatial optimization as a generative technique for sustainable multiobjective land-use allocation, International Journal of Geographical Information Science, 22(6), pp. 601-622.

Malczewski, J. (1991) Central facility location and environmental health, Environment and Planning A, 23(3), pp. 385-395.

Malczewski, J. (1996) A GIS-based approach to multiple criteria group decision making, International Journal of Geographical Information Science, 10(8), pp. 955-971.

Malczewski, J. (1999) GIS and Multicriteria Decision Analysis (New York: John Wiley).

Malczewski, J. (2006a) GIS-based multicriteria decision analysis: A survey of the literature, International Journal of Geographical Information Science, 20(7), pp. 703-726.

Malczewski, J. (2006b) Ordered weighted averaging with fuzzy quantifiers: GIS-based multicriteria evaluation for land-use suitability analysis, International Journal of Applied Earth Observation and Geoinformation, 8(4), pp. 270-277.

Malczewski, J. \& Ogryczak, W. (1995) The multiple criteria location problem: 1. Generalized network model and set of efficient solutions, Environment and planning A, 27(12), pp. 1931-1960.

Malczewski, J. \& Ogryczak, W. (1996) The multiple criteria location problem: 2. Preference-based techniques and interactive decision support, Environment and Planning A, 28(1), pp. 69-98.

Malczewski, J., Moreno-Sanchez, R., Bojorquez-Tapia, L. A. \& Ongay-Delhumeau, E. (1997) Multicriteria group decision-making model for environmental conflict analysis in the Cape Region, Mexico, Journal of Environmental Planning \& Management, 40(3), pp. 349-374.

Maniezzo, V., Mendes, I. \& Paruccini, M. (1998) Decision support for siting problems, Decision Support Systems, 23(3), pp. 273-284.

Minor, S. D. \& Jacobs, T. L. (1994) Optimal land allocation for solid- and hazardous-waste landfill sitting, Journal of Environmental Engineering, 120(5), pp. 1095-1108.

Natividade-Jesus, E., Coutinho-Rodrigues, J. \& Antunes, C. H. (2007) A multicriteria decision support systems for housing evaluation, Decision Support Systems, 43(3), pp. 779-790.

Pereira, J. M. C. \& Duckstein, L. (1993) A multiple criteria decision-making approach to GIS-based land suitability evaluation, International Journal of Geographical Information Systems, 7(5), pp. 407-424.

Saaty, T. (1980) The Analytic Hierarchy Process (New York: McGraw-Hill). 
Shirabe, T. (2005) A model of contiguity for spatial unit allocation, Geographical Analysis, 37(1), pp. 2-16. Voogd, H. (1983) Multicriteria Evaluation for Urban and Regional Planning (London: Pion Ltd).

Williams, J. C. (2003) Convex land acquisition with zero-one programming, Environment and Planning B: Planning and Design, 30(2), pp. 255-270.

Zucca, A., Sharifi, A. M. \& Fabbri, A. G. (2007) Application of spatial multi-criteria analysis to site selection for a local park: A case study in Bergamo Province, Italy, Journal of Environmental Management, 88(4), pp. 752-769. 